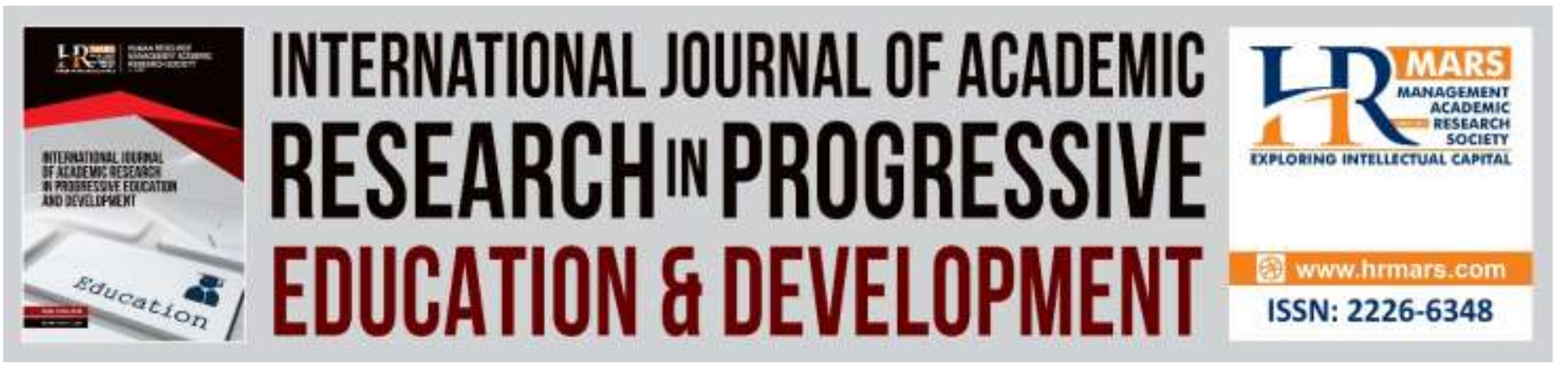

\title{
Verse of Mutasyabihat Pronouncement in Tahfiz Al-Quran Education: An Early Survey
}

\author{
Azizul Bin Hassan \\ Mohd Norhafizi Bin Yusof
}

To Link this Article: http://dx.doi.org/10.6007/IJARPED/v8-i2/5683

DOI: $10.6007 /$ IJARPED/v8-i2/5683

Received: 28 Feb 2019, Revised: 23 March 2019, Accepted: 07 April 2019

Published Online: 25 April 2019

In-Text Citation: (Hassan \& Yusof, 2019)

To Cite this Article: Hassan, A. Bin, \& Yusof, M. N. Bin. (2019). Verse of Mutasyabihat Pronouncement in Tahfiz Al-Quran Education: An Early Survey. International Journal of Academic Research in Progressive Education and Development, 8(2), 102-112.

Copyright: (C) 2019 The Author(s)

Published by Human Resource Management Academic Research Society (www.hrmars.com)

This article is published under the Creative Commons Attribution (CC BY 4.0) license. Anyone may reproduce, distribute, translate and create derivative works of this article (for both commercial and non-commercial purposes), subject to full attribution to the original publication and authors. The full terms of this license may be seen

at: http://creativecommons.org/licences/by/4.0/legalcode

Vol. 8(2) 2019, Pg. 102 - 112

http://hrmars.com/index.php/pages/detail/IJARPED

JOURNAL HOMEPAGE

Full Terms \& Conditions of access and use can be found at http://hrmars.com/index.php/pages/detail/publication-ethics 


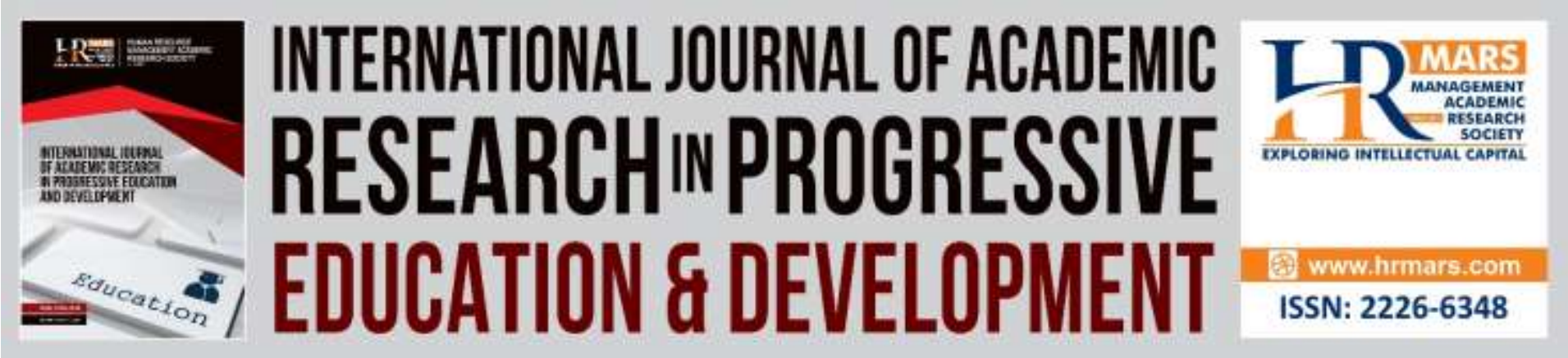

\title{
Verse of Mutasyabihat Pronouncement in Tahfiz Al- Quran Education: An Early Survey
}

\author{
Azizul Bin Hassan \\ Maahad Tahfiz Al-Quran Terengganu (MTQT) \\ Mohd Norhafizi Bin Yusof \\ Universiti Sultan Zainal Abidin (UniSZA)
}

\begin{abstract}
Verse of Mutasyabihat pronouncement is one of the important elements in the language style of al-Quran. Its existence proves that Allah SWT encourages His servants to practise thinking culture and deep contemplation of the contents in al-Quran. In context of al-Quran memorisation subject, verse of Mutasyabihat pronouncement is a challenge which must be faced by every memoriser of al-Quran mastered with excellence. Therefore, this paperwork is framed aiming to recognise the concept for verse of Mutasyabihat pronouncement and its importance among the huffaz of alQuran. Thus, it is suggested that the huffaz of al-Quran are given further exposure regarding verse of Mutasyabihat pronouncement from the aspect of cognition, implementation method in the memorisation and formation of specific subject related to verse of Mutasyabihat. Hope of the researcher is that this academic study regarding the memorisation of al-Quran and verse of Mutasyabihat pronouncement is continuously performed to produce competitive huffaz of alQuran.
\end{abstract}

Keywords: Mutasyabihat Pronouncement, Huffaz Of Al-Quran

\section{Introduction}

Al-Quran is a book of miracle from every aspect of its contents. This situation proves that very information in it cannot be challenged by anyone. History proves that al-Quran is able to amaze human and djinn until they bow annd obey the teachings of al-Quran without doubt. Among the attributes of miracles in al-Quran is through the usage of high and fluent language style such as aspects of balaghah, al-mithal and verse of Mutasyabihat pronouncement. In this tiny paperwork, the researcher chooses the miracles of al-Quran from the aspect of verse of Mutasyabihat pronouncement as the subject of discussion as it is an aspect which that gets less attention from the perspective of reading, learning and academic research (al-Syatariy, 2004). Therefore, the need of reviewing its background and important matters related to verse of Mutasyabihat 
INTERNATIONAL JOURNAL OF ACADEMIC RESEARCH IN PROGRESSIVE EDUCATION AND DEVELOPMENT

Vol. 8, No. 2, 2019, E-ISSN: $2226-6348$ @ 2019 HRMARS

pronouncement should be incerased. In this paper, the researcher ttries to describe several aspects for verse of Mutasyabihat pronouncement baased on their importance.

Generally, Mutasyabihat verse is divided into two main categories which are verse of Mutasyabihat meaning and verse of Mutasyabihat pronouncement (al-Hunayn, 2008), however this paper only focuses on verse of Mutasyabihat pronouncement. Mutasyabihat literally is defined as resembling vagueness (al-Jauhari, 1990), vagueness from the attribute and colour (Zakaria, 1999), two things resembling in phyical aspect such as colour and food or abstract aspect such as justice and injustice (al-Asfahani, 2001), vagueness that happens due to small difference between each other (alZamakhsyari, 1978), variety between each other (al-Razi, 1994) and vaguness caused by mixing between each other (al-Fayumi, n.d.).

Based on the definition, it can be concluded that the literal meaning of mutasyabihat touches two aspects which are the similarity of meaning and diversity of variation (Bahuyarith, n.d.). Meanwhile, technical definition of mutasyabihat is the similarity of pronouncement from manifest aspect but differs from meaning aspect (Qutaybah, 1973) and problem that needs scrutiny (alManawiy, 1989).

While for Mutasyabihat pronouncement, it means the repetition of the same verse with same or different words, resembling nearly similar letters and needs for certain method to remove the vagueness (al-Asfahaniy, 2001). Besides that, Mutasyabihat pronouncement also means the repetition of al-Quran pronouncements which have similar pronouncement but with addition, reduction and change of letter with other letters (al-Kirmaniy, n.d). Mutasyabihat pronouncement is also defined as repetition of Quranic verse from the aspect of word coming earlier or later or addition that happens in its language style (Jama'ah, 1990).

Thus, verses of mutasyabihat pronouncement are verses of al-Quran which have repeated pronouncements, or there is difference between each others even of a letter besides having closely similar meaning (Tahaniy, n.d.).

\section{Issues Related to Verse of Mutashabihat Pronouncement}

This survey was done because the factor of memorisation mistakes is the vagueness towards the verse of mutasyabihat pronouncement (Minyar, 2003). This situation occured in view of that every memoriser of al-Quran has different levels of memorising and the pattern of verse of mutasyabihat pronouncement which is almost similar between each other in the aspect of pronouncement and verse. This is supported by a study performed by Abdullah et al. (2003) doing research related to memorisation method of al-Quran. Through the study, a number of 129 students from 335 respondents stated that they faced problem in memorising verse of mutasyabihat pronouncement. The number of the respondents represented $41.4 \%$ from the total of respondents. Even though the total of respondents who faced problem memorising verse of mutasyabihat pronouncement is lower than students who did not have problem regarding it, the study was only in the form of research question and not in the form of true test that can recognise the exact mastery level of each respondent. 
INTERNATIONAL JOURNAL OF ACADEMIC RESEARCH IN PROGRESSIVE EDUCATION AND DEVELOPMENT

Vol. 8, No. 2, 2019, E-ISSN: $2226-6348$ @ 2019 HRMARS

Besides that, the pattern of verse of mutasyabihat pronouncement reaches 2000 to 7500 places or 1200 to 2000 (Abdullah et al., 2003) verses in al-Quran. The total represents $1 / 3$ from the total 6236 verses of al-Quran according to al-Kufiyy sect (al-Jabaliy, 2012). Moreover, its disuniform position and small difference such as addition and reduction of a letter complicate the huffaz to know the difference of the verse of mutasyabihat pronouncement.

This situation keeps on happening although the past scholars have paid a deep attention to the examination of verse of mutasyabihat pronouncement. This can be witnessed by the production of writings on verse of mutasyabihat pronouncement in the early second century by Imam 'Ali Hamzah al-Kisa'iy and Imam Nafi al-Madaniyy (al-Sayyid, 2009). Then, the production of various versions of book for mutasyabihat pronouncement was continued by scholars such as writing of books and poetic stanzas which were compiled more systematically. However, the problem in differentiating the verse of mutasyabihat pronouncement still occurs and recurs among the huffaz (Abdullah et al., 2005). Even a hafiz cannot be said to be skillful in his memorisation as long as he has not mastered the verse of mutasyabihat pronouncement yet (Abdullah et al., 2003).

The observation of teacher in the teaching and learning process of al-Quran memorisation becomes an important factor in assisting the resolution of the problem. This is in virtue of the fact that the students are more comfortable using personal method to differentiate the verse of mutasyabihat pronouncement even though they are guided by the teacher in the class. The matter happens due to the teaching provided by the school of tahfiz institution which is verbal and informal. Besides that, from the observation by majority of the researchers of Maahad Tahfiz alQuran throughout the country, Public and Private Institution of Higher Education do not offer subject regarding verse of mutasyabihat pronouncement specifically to the students in field of alQuran, either at certificate, diploma, bachelor or master level.

From the researchers' observation also, among other factors contributing to the occurence of problem among the huffaz of al-Quran in Malaysia is the lack of writing materials, studies and researches in this field which are written and studied by the researchers (al-Jabaliyy, 2012). This situation does not happen because the distribution of information related to verse of mutasyabihat pronouncement is not performed extensively and this phenomenon is seen to happen to the writing of "al-Asrar al-Tikrar Fi al-Qur'an" book by al-Kirmaniyy. Even though the book is known as an important reference by past scholars, the propagation and exposure of this book do not spread widely among the public. This leads to a blocked and stunted understanding of verse of mutasyabihat pronouncement in the community.

\section{Progress of Verse of Mutashabihat Pronouncement}

Knowledge of Mutasyabihat Pronouncement underwent through several phases of development as recorded by past Islamic intellects. This can be seen due to clashes of view among the researchers of Mutasyabihat Pronouncement field to determine its level of development. Among them, the view posed by Muhammad Mustafa 'Aydin by dividing the development of Mutasyabihat Pronouncement knowledge into four main phases which are phase of writing, book binding, 
compilation of Mutasyabihat Pronouncement according to order of surah and phase of meaning elaboration (al-Iskafiy, 2001). Meanwhile, al-Birkah in his study stated that the development of Mutasyabihat Pronouncement knowledge has gone through five main phases which are the era of book binding, phase of book binding, meaning elaboration, compilation in the form of poems and focused research (al-Birkah, 2009). According to the posed views, the researchers concluded that the development of Mutasyabihat pronouncement knowledge is as follows:

\section{First Phase}

In this phase, the researchers opined that the discussion of Mutasyabihat Pronouncement knowledge has existed since the time of Prophet SAW, however the development does not spread widely due to priority of preaching on the oneness of Allah SWT at the time. This situation occured after going through several narrations of hadis by Prophet SAW signifying the verse of mutasyabihat pronouncement:

ما روي عن أبي أمامة عن النبي-صلى الله عليه وسلم- قال : أن اسم الله الأعظم لفي ثلاث سور من القرآن : في سورة البقرة، وآل آل إل إله

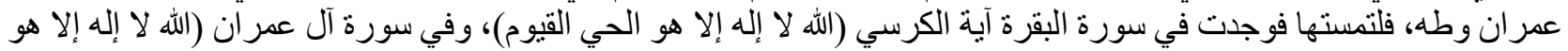
الحي القيوم) وفي سورة طه (و عنت الوجوه فورة للحي القيوم).

Meaning: "Narration from Abu Umamah from Prophet SAW saying; Indeed the name of Allah the Exalted One exists in three chapters of al-Quran which are in surah al-Baqarah, ali Imran and taha,

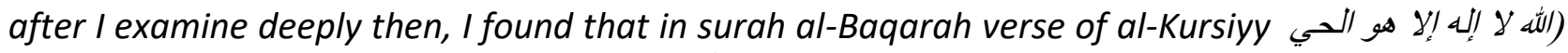
(القبوم), in surah ali Imran (الله لا إله إلا هو الحي القبوم) and in surah taha (وعنت الوجوه للحي القبيوم)" (al-Albaniy, 2002).

From the view of researchers, even though the hadis does not indicate clearly the verse of mutasyabihat pronouncement, the usage of the word (فiالتََسَنْتُهَا) signifies that the subject being in focus is the similar and closely similar verses in different chapters which is the phrase (الحَيُّ القَيُّمُم). The properties is one of the elements contained in verse of mutasyabihat pronouncement. This situation visualises that verse of mutasyabihat pronouncement has been discussed since the time of Prophet SAW and the first person making it as the subject of discussion is Prophet SAW himself. Comprehensively, if Prophet SAW himself showed the track of discussion towards verse of mutasyabihat pronouncement, then it indicates the position of verse of mutasyabihat pronouncement is so special and deeper examination must be continued.

\section{Second Phase}

The progress of knowledge on verse of mutasyabihat pronouncement at this time results from bunches of idea by qurra' who focused on the aspect of al-Quran memorisation (Ibn al-Nadim, 1997) around the second century of hijrah. They found that the huffaz of al-Quran were experiencing difficulties in differentiating the verse of mutasyabihat pronouncement (al-Jabaliy, 2012). Therefore, they began to emphasise on it specifically in the learning of al-Quran. Focus of the discussion only highlights the method of compilation and arrangement of verses of mutasyabihat pronouncement to ease the hafiz of al-Quran in differentiating them without 
INTERNATIONAL JOURNAL OF ACADEMIC RESEARCH IN PROGRESSIVE EDUCATION AND DEVELOPMENT

Vol. 8, No. 2, 2019, E-ISSN: 2226-6348 @ 2019 HRMARS

elaborating on the difference from the aspect of meaning, secret and wisdom of its existence in alQuran (al-Sayyid, 2009).

After that, knowledge on verse of mutasyabihat pronouncement starts to progress widely in the more systematic form through the efforts of some scholars from mu'tazilah sect such as Basyar Bin al-Mu'tamar al-Hilali, as the leader of mu'tazilah group in Baghdad at that time, then it was developed further by Abu 'Ali Muhammad al-Mustanir through his book "Al-Radd 'Ala al-Mulhidin Fi Mutasyabih al-Qur'an" (Ibn al-Nadim, 1997). Other than that, Al-Qadi Abdul Jabbar Al-Hamadani also play his role to develop this knowledge through his writing "Mutasyabih al-Qur'an" and his recognised position as one of the great scholars of mu'tazilah at that time (al-Sayyid, 2009).

Later, around the early fourth century of hijrah, knowledge on verse of mutasyabihat pronouncement started to be explored by the Sunni scholars. Among the earliest scholars responsible todevelop it is 'Abu 'Abdullah Muhammad Bin 'Abdullah al-Iskafiyy through his work "Durrah al-Tanzil Wa Ghurrah al-Ta'wil" until the book becomes the main reference to the method writing book on verse of mutasyabihat pronouncement for the later scholars. Revolution of knowledge on mutasyabihat pronouncement keeps on upgraded by the scholars through compilation of the knowledge in poetic stanzas as the habit of Arabic intellects to modify other certain knowledge that it is easier to be memorised, learnt and inherited. Imam Al-Sakhawiyy is the pioneer of this method through his work "Hidayah al-Murtab Wa Ghayah Al-Huffaz Wa AlTullab fi al-Tabyin Mutasyabih Al-Kitab" and then adapted by later scholars such as Imam Abu Syamah Al-Maqdisiyy, Imam Muhammad Hasyim Al-Sanadiyy and Imam Al-Dimyatiyy and ended with Imam Zakaria Al-Ansariyy (al-Jabaliy, 2012).

Despite, the development of knowledge on verse of mutasyabihat pronouncement halted until around 500 years which was after the decease of Imam Zakaria Al-Ansariyy in year 926 Hijrah and was resumed by Fadil Al-Samura'iyy in early year 1400 Hijrah. He pioneered the knowledge by adding new elements in the effort of preserving legitimation of past scholars in explaining the knowledge on verse of mutasyabihat pronouncement until now.

\section{Third Phase}

Third Phase is the last phase in the development of knowledge on verse of mutasyabihat pronouncement in which the variety of methods and techniques applied to elaborate verse of mutasyabihat pronouncement proves that contemporary scholars keeps on serving vigorously towards these unique words of Allah SWT. Improvement happening in this phase does not bind to to only conventional method, but it is also extended to form of discussion forum through internet mediation, special slot in television, writing in the form of dictionary and begins to to be chosen as study material in academis researches (al-Jabaliy, 2012).

The discussion held is not only limited only to difference and elaboration of the meaning, indeed they also discuss the verse of mutasyabihat pronouncement from diversity of knowledge aspect such balaghah, i'jaz, secret of verse arrangement and usage of certain letters until some among them perform ijithad in providing accurat meaning to the interpretation of verse of mutasyabihat 
pronouncement according to their level of scholarship (al-Sayyid, 2009). This proves that the knowledge is not static in nature, and indeed it is flexible and able to open a new sheet in passing across other related knowledge such as fiqh and aqidah (al-Sayyid, 2009).

However, the happening positive progress does not mean that discussion on verse of mutasyabihat pronouncement has achieved maximal level, indeed effort towards widening researches regarding it should be continued.

\section{Division of Mutasyóbihót Pronouncement}

Scholars have divided verses of mutasyabihat pronouncement into several components, however the researchers only elaborated only the components in verse of mutasyabihat pronouncement significant with the study. Details for the components are as follows:

\section{Tikrar Al-Lafz}

Language style of pronouncement repetition تكرار اللفظ) is one of the high language styles from the aspect of rhetoric knowledge (balaghah). The existence of this component is with purpose and focus. Despite, there is an allegation saying that this component is less beneficial and less important. Al-Zarkasyi (n.d.) explained that this component is one of the characteristics of uniqueness and beauty of al-Quran language style. The component is included in al-Quran aiming to serve as reminder, emphasis, description of paradise bounties and hell torments. Therefore, repetition of al-Quran verses either with same pronouncement, or slightly different one, is needed by human as reminder from slackness and carelessness.

Besides that, pronouncement repetition also aims to strengthen a meaning (al-Suyuti, 1979), and is able to provide meaning from aspect of religion and fineness of language (al-Mut'iniy, 1992). Example of this component is in surah al-Rahman which is the verse :

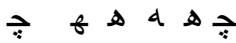

Meaning: "Then which of the God's bounties that you deny?"

This verse is repeated from 31 times but it carries different meanings depending on the contect of the previous verse. The first eight verses indicate the miracles of Allah SWT's creations, later seven verses describe the torments of hell and bounties of paradise, laater eight verses visualise the condition of paradise and its dwellers and the last eight verses explain the condition of two paradises other that the one stated before (al-Kirmaniy, n.d).

\section{Al-Ziyadah Wa Al-Nuqsan}

This component is also named as al-dzikr (الذكر ) or al-hazf ( الحذف ) which is the word mentioned and reduced in verse of mutasyabihat pronouncement (al-Qarsyiyy, 2011), Al-Jurjani (1983) said that it is included into category of sentence that needs detailed examination. This is because in certain condition the element of hazf in the verse of al-Quran is understood more easily than pronouncing it. This component is divided into three parts which are the addition and reduction of a letter, word or more than a word (al-Qarsyiyy, 2011). 
INTERNATIONAL JOURNAL OF ACADEMIC RESEARCH IN PROGRESSIVE EDUCATION AND DEVELOPMENT

Vol. 8, No. 2, 2019, E-ISSN: 2226-6348 @ 2019 HRMARS

\section{Al-Taqdim Wa Al-Ta'khir}

This component is one of the characteristics of pronouncement description scrutiny in al-Quran. Al-Taqdim Wa Al-Ta'khir is the arrangement of certain pronouncements in verse of mutasyabihat pronouncement from the aspect of its position in the verse, either it is put first or last (al-Qarsyiyy, 2011). It is a beneficial component of al-Quran as it provides more accurate, deeper, more easily understood and detailedly presented meaning (al-Jurjani, 1983). This pictures that the pronouncement condition of al-Quran owns a very deep meaning elaboration, which then through this component can make prominent the miracle of al-Quran. It is divided into three parts which are at the level of word, verse and pronouns (al-Tahani, n.d).

\section{Al-Ma'rifah Wa Al-Nakirah}

This component is the difference from the aspect of pronouncement usage in al-Quran either in the form of Common Noun or Proper Noun. Al-Ma'rifah Wa Al-Nakirah owns a special and important position in al-Quran (al-Qarsyiyy, 2011). Even though its difference is only small such as the usage of lam ta'rif and tanwin however, it affects the meaning of verse and students' memorisation. Hence, mastery of memorisation which is tested to this component is appropriate to be performed.

\section{Al-Mufrad Wa Al-Jam'}

This component is the difference in the aspect of word morphology either in the singular or plural form. Al-Mufrad Wa Al-Jam' in al-Quran depends on context of the verse or the previous verse aiming to provide deeper meaning. Past scholars have attended deeply to this aspect.

\section{Ibdal Al-Harf Wa Al-Kalimah}

This component is the difference in the aspect of change in letter, word or verse in al-Quran. This visualises that the pronouncement of al-Quran substituted in the verse of mutasyabihat pronouncement based on the meaning of the verse is very accurate and there is no other word that can replace it even though it is similar literally.

\section{The Importances and Benefits of Verse of Mutasyóbihót Pronouncement}

History has proved that the zindiq, atheist and extremist group have chosen the verse of mutasyabihat pronouncement as a material to confuse the community on its existence as something vague and useless (al-Sayyid, 2009). Initiated by the situation, scholars of Islam have put their extensive effort to ensure that the doubt, hesitation and supposition raised on verse of mutasyabihat pronouncement can be harmonised. Conclusively, verse of mutasyabihat pronouncement is seen important as follows:

1) Encouragement and urge from the scholars so that the field of mutasyabihat pronouncement can be intensified continuously.

2) Expressing the authority of each scholar steeping into the field of mutasyabihat pronouncement, as if all verses of al-Quran are in the Mulkam form, the door to perform ijtihad will be closed and this contradicts with the teachings of Islam that encourage its people to read and contemplate. 
3) Giving space to increase reward to Muslim community due to difficulty faced in interpreting the verse of mutasyabihat pronouncement

4) Commencement of ijtihad towards verse of mutasyabihat pronouncement needs to the mastery of other knowledge related to it such as knowledge of Arabic language, Balaghah, Usul al-Fiqh and others. Thus, this situation stimulates the researchers on verse of mutasyabihat pronouncement to endeavour in increasing and integrating the mastered knowledge.

\section{Conclusion}

Therefore, Al-Quran is a book that contains many miracles as evidence that it is not of human's idea and invention. Miracles of al-Quran encompass all aspects such as judiciary, language style, science, qiraat version and others. Every aspect of its miracle has been paid full attention by past and present Islamic scholars. Despite, if the subjects are compared with verse of mutasyabihat pronouncement then, it is found that the number of past scholars and modern researchers studying it is still low.

Thus, the discussion scope and propagation of knowledge on verse of mutasyabihat pronouncement should be widened to ensure that its existence is realised and understood by each of Muslim community. This is in virtue of that deep comprehension on verse of mutasyabihat pronouncement could bring a new and fresh paradigm towards the interpretation of al-Quran and consequently preserves the legacy of precious heritage by the past scholars.

\section{References}

Al-Iskafiyy A.A. (2001). Durrah al-Tanzil wa Ghurrah al-Ta'wil. Maahad Buhuth al-'Ilmiyyah.

Al-Manawiyy, A.R. (1989). Al-Tauqif 'ala Muhimmat al-Ta'rif. Beyrut: Dar al-Fikr.

Al-Suyutiyy, J, (1979). Al-Itqan Fi Ulum al-Qur'an. Beyrut: Dar al-Fikr.

Al-Mut'iniyy, A.A. (1992). Khasais al-Ta'bir al-Qur'aniyy Wa Simatih al-Balaghiah. Cairo: Maktabah Wahbah.

Al-Jurjaniyy, A.Q. (1983). Dalail al-'ljaz. Beyrut: Dar al-Kutub al-'Arabiyy.

Qutaybah, A.M. (1973). Ta'wil Musykil al-Quran. Cairo: Dar al-Turath.

Al-Warraqiyy, A. (n.d.). Ighasah al-Luhfan Fi Dabt Mutasyabih al-Quran. Iskandariah: Dar al-Iman. Abdullah, A.H. (2003). Keberkesanan Kaedah Hafazan Satu Kajian, Shah Alam: Universiti Teknologi Malaysia.

Al-Fayumiyy, A.M. (n.d.) al-Misbah al-Munir Fi Gharib al-Syarh al-Kabir Li al-Rafi'iyy. Beyrut: alMaktabah al-IImiah.

Al-Asfahaniyy, R. (2001). Mufradat Gharib al-Quran. Beirut: Dar al-Ma'rifah.

Al-Sayyid, S. (2009). Safwah al-Bayan Fi Mutasyabih al-Nuzm Fi al-Quran. Cairo: Dar al-Kutub alMisriyyah.

Abdullah, A.H. (2005) Sistem Pembelajaran Dan Kaedah Hafazan Al-Quran Yang Efektif: Satu Kajian Di Kuala Lumpur Dan Terengganu, Universiti Teknologi Malaysia.

Badr al-Din Bin Jama'ah. (1990). Kasyf al-Ma'ani Fi al-Mutasyabih Min al-Mathani. Mansurah: Dar al-Wafa'. 
INTERNATIONAL JOURNAL OF ACADEMIC RESEARCH IN PROGRESSIVE EDUCATION AND

DEVELOPMENT

Vol. 8, No. 2, 2019, E-ISSN: 2226-6348 @ 2019 HRMARS

Khairudin, W.M.K.F.W., Embong, A.H., Anas, W.N.I.W.N., Mohd, H. \& Ismail, D. (2018), The Application of Technology in the Dissemination of Fatwas: A Study on Religious Institutions in Malaysia, International Journal of Civil Engineering and Technology, 9(7), 2018, pp. 15901596.

Khairuldin, W.M.K.F.W., Ismail, D., Anas, W.N.I.W.N., Ibrahim, I., \& Fauzi, N. (2016). Freedom of Speeches by Mufti According to Islam: Implication to Fatwa in Malaysia. International Journal of Academic Research in Business and Social Sciences. 6 (12). Pp 141-151.

Khairuldin, W.M.K.F.W. (2016). Konsep Fatwa dalam Islam. Kuala Terengganu: Penerbit UniSZA.

Khairuldin, W. M. K. F. W., Anas, W. N. I. W. N., \& Embong, A. H. (2018). Fatwa as a Disseminator of Islamic Laws among Community of Malaysia. International Journal of Academic Research in Business and Social Sciences, 8(11), 516-521.

Khairuldin, W.M. K. F. W. (2018). Fatwa Role in Education and Legal Dispute in Malaysia. International Journal of Academic Research in Progressive Education and Development, 7(4), 295-302.

Khairuldin, W. M. K. F. W., Anas, W. N. I. W. N., \& Embong, A. H. (2018). The Binding of Laws to Personal Opinion of Muftis in Malaysia. International Journal of Academic Research in Business and Social Sciences, 8(11), 522-529.

Khairuldin, W. M. K. F. W., Embong, A. H., Anas, W. N. I. W. N., Ismail, D., \& Mokhtar, W. K. A.W. (2019). An Augmented Reality (AR) Approach in Educational Integration of Du'a in Islam. International Journal of Academic Research in Progressive Education and Development, 8(1), 32-39.

Khairuldin, W. M. K. F. W., Embong, A. H., \& Anas, W. N. I. W. N. (2019). Technological Approach in Education of Musafir (Muslim Traveler) in Islam: The Study on Mobile App Mysafar. International Journal of Academic Research in Progressive Education and Development, 8(1), 40-47.

Zallath, M.R. (2014). Aisar Al-Turuq, Al-Qahirah: Dar Al-Sahabah.

Yasin, M.F.M., Embong, A.H., Khairuldin, W.M.K.F.W., Rahim, R.S.A., Abdullah, A., Said, S. \& Mutalib, N.A. (2018). Contributions of Technology Towards Development Of Qur'anic Tajweed Knowledge, International Journal of Civil Engineering and Technology, 9(6), 2018, pp. 1340-1352

Al-Zarkasyiyy, B.D. (n.d). Al-Burhan Fi Ulum al-Qur'an, Cairo: Maktabah Dar al-Turath.

Al-Hunayn, F. (2008). Al-Dabt Bi al-Taq'id Limutasyabih al-Lafz Fi al-Quran al-Majid, Riyadh: Maktabah al-Malik Fahd al-Wataniah.

Ibn al-Nadim, M.I. (1997). Fahrasat, Beirut: Dar al-Ma'rifah.

Al-Jauhariyy, I. (1990). Al-Sihah Taj al-Lughah wa al-Sihah al-Arabiah. Beirut: Dar al-Ilm al-Malayin. Al-Kirmaniyy, M. (n.d.). Asrar al-Tikrar Fi al-Quran al-musamméa al-Burhan Fi Taujih Mutasyabih al-Quran Lima Fih Min al-Hujjah Wa al-Bayan, Cairo: Dar al-Fadilah.

Al-Zamakhsyariyy, M. (1978). Asas al-Balaghah, Beyrut: Dar al-Fikr.

Al-Qarsyiyy, M. (2011). Balaghah al-Mutasyabih al-Lafz Fi Tafsir al-Bahr al-Muhit li Abi Hayyan. Doctorate thesis, Universiti Umm al-Qura, Mekah, Arab Saudi.

Al-Raziyy, M. (1994). Mukhtar al-Sihah. Beyrut: Maktabah Lubnan Nasyirun.

Al-Iskafiyy, M. (2001). Durrah al-Tanzil Wa Ghurrah al-Ta'wil. Mecca: Matbu'at Jami'ah Umm alQura. 
Al-Albaniyy, M.N. (2002). Silsilah al-Ahadith Al-Sahihah. Riyadh : Maktabah al-Ma'arif.

Al-Jabaliyy, M. (2012). Taujih al-Mutasyabih al-Lafziyy Fi al-Quran al-Karim Bayn al-Qudama' Wa al-Muhdathin : Ahmad al-gharnaï̈y Wa Fadil al-Samura'iyy Dirasah Muqaranah, Kuala Lumpur, Universiti Malaya: Akademi Pengajian Islam.

Al-Birkah, M.R. (2009). Al-Mutasyabih al-Lafziyy Fi al-Qur'an al-Karim Wa Taujihuhu : Dirasah Maudu'iyyah, Riyadh: Jamiah al-Imam Muhammad bin Sa'ud.

Minyar, M. (2003). I'anah al-Huffaz Li al-Ayat al-Mutasyabihat al-Alfaz. Jeddah: Al-Hay'ah al'Alamiah Li al-Tahfiz al-Qur'an.

Al-Syitariyy, S. (2004). Al-Mutasyabih al-Lafziyy Fi al-Qur'an al-Karim Wa Asraruhu al-Balaghiah, Medina: Mujjama' al-Malik Fahd.

Bahuyarith, T, (n.d.). 'Athar Dilalah al-Thiyaq al-Quraniyy Fi Taujih Ma'ani al-Mutasyabih al-Lafziyy Fi al-Qisas al-Quraniyy, (Makkah al-Mukarramah, Master thesis of Tafsir and Ulum alQuran. 